\title{
Evaluation of microbiological quality in fresh sushi samples
}

\author{
Halil YALÇIN ${ }^{1}$, Tuncer ÇAKMAK²
}

${ }^{1}$ Burdur Mehmet Akif Ersoy University, Faculty of Veterinary Medicine, Department of Food Hygiene and Technology, Burdur/TURKEY

${ }^{2}$ Van Yuzuncu Yil University, Faculty of Veterinary Medicine, Department of Food Hygiene and Technology, Van/TURKEY

Key Words:

food hygiene

public health

microbiological quality

sushi

\section{Anahtar Kelimeler: \\ gida hijyeni \\ halk sağlığ1 \\ mikrobiyolojik kalite \\ suși}

Received: 27.01.2020

Accepted: 05.03.2020

Published Online: 30.04.2020

Article Code:680767

Correspondence:

T. CAKMAK

(tuncercakmak@yyu.edu.tr)

ORCID:

H. YALÇIN: 0000-0003-2162-2418

T. CAKMAK: 0000-0002-9236-8958

\begin{abstract}
In this study, it is aimed to determine the microbiological quality of 60 different raw salmon finger sushi (maki rolls) samples randomly supplied from consumption points (sushi bar, sushi buffet, hotel, restaurant etc.) serving fresh sushi. The counts of Escherichia coli, coagulase-positive Staphylococcus aureus, Vibrio paraheamolyticus and Salmonella spp. presence (+/-) were examined in these samples for the detection of hygienic quality and pathogenic microorganisms. Twenty-nine of 29/60 (48.3\%) samples were found to be positive for these microorganisms. Salmonella spp. presence was detected in $2 / 60$ samples $(3.3 \%)$ while coagulase-positive $S$. aureus was found in $10 / 60$ samples $(16.7 \%)$ with the highest level of $4.84 \log \mathrm{CFU} / \mathrm{g}$. E. coli was detected in 15/60 samples (25.0\%), $V$. paraheamolyticus was determined in 13/60 samples (21.7\%) with a level of $2.90 \mathrm{log} \mathrm{CFU} / \mathrm{g}$ and $2.82 \mathrm{log} \mathrm{CFU} / \mathrm{g}$, respectively. Based on the current findings, it is considered that microorganisms determined in the samples pose a risk to public health, authorities should mandate to conduct routine inspections more frequently and businesses selling sushi should be included in the annual sampling plan. It will be beneficial for healthy sushi production that it should be paid attention to hygienic production during the all manufacturing, storage and service stages and points of sale and relevant staff should be ensured to routinely receive necessary food safety training to minimize the risk of foodborne disease outbreaks.
\end{abstract}

\section{Taze suşi örneklerinde mikrobiyolojik kalitenin değerlendirilmesi}

\section{ÖZ}

Bu çalışmada; taze suşi servisi yapan rastgele seçilmiş tüketim noktalarından (sushi bar, sushi büfe, otel, restorant vs.) temin edilen toplamda 60 adet çeşitli çiğ somon parmak suşi (maki rolls) örneklerinin mikrobiyolojik kalitelerinin belirlenmesi amaçlanmıștır. Örneklerde hijyenik kalitenin ve patojen mikroorganizmaların tespit edilmesine yönelik Escherichia coli, koagulaz pozitif Staphylococcus aureus, Vibrio paraheamolyticus sayıları ile Salmonella spp. (+/-) varlığ1 araştırılmıştır. İncelenen mikroorganizmalar yönünden 29/60 (\%48,3) örneğin pozitif olduğu görülmüștür. 2/60 örnekte (\%3,3) Salmonella spp. varlığ̣ tespit edilirken, koagulaz pozitif S. aureus'un 10/60 (\%16,7) örnekte ve en yüksek $4.84 \mathrm{log} \mathrm{KOB} / \mathrm{g}, \mathrm{E}$. coli’nin 15/60 (\%25,0) örnekte ve V. paraheamolyticus'un 13/60 örnekte $(\% 21,7)$ sirasiyla ortalama 2.90 $\log \mathrm{KOB} / \mathrm{g}$ ile $2.82 \log \mathrm{KOB} / \mathrm{g}$ olduğu saptanmıştır. Mevcut bulgulara dayanarak, örneklerde tespit edilen mikroorganizmaların halk sağlığı açısından riskler taşıdığı, yetkili otoritelerin daha sık rutin denetimler yapması ve suşi satışı yapan işletmelerin yıllık numune planına dahil edilmesi gerektiği düşünülmektedir. Gıda kaynaklı hastalık salgınları riskini en aza indirgemek için suşi üretim ve satış yerlerinde tüm üretim, muhafaza ve servis aşamalarında hijyenik üretime önem verilmesi ve ilgili personellerin rutin olarak gerekli gıda güvenliği eğitimini almalarının sağlanması sağlıklı suşi üretimi açısından faydalı olacaktır. is based on manufacturer choices and local preferences. It is prepared with raw farmed salmon, tuna, and halibut, whiting, cooked scampi, large freshwater prawns, and raw vegetables such as cucumber, spring onion (scallions), and avocado $(5,6)$. It is a popular ready-to-eat (RTE) food preferred by consumers and offered cold at $4{ }^{\circ} \mathrm{C}$ with a sell-by date of 2 to 3 days after production which is served directly to human consumption without cooking or other processes to eliminate or reduce microorganisms to an acceptable level by manufacturers or businesses (6). Intrinsic factors (high water activity, nearneutral $\mathrm{pH}$ ) of fish meat and raw fish products provide a favorable condition for microorganisms to develop and can cause spoilage within the whole process from the moment of catching of fish to consume in the presence of extrinsic 
factors (harvest, hunting, transportation, process, storage etc.) (7). It carries some potential health hazards due to possible contamination of pathogenic microorganisms during raw material, process and storage. Monitoring of microbiological quality is also important to prevent food poisoning cases $(3,6,8,9)$. Sushi is consumed similar to other fast foods without additional heat treatment to reduce microbial load. Therefore, forms of raw seafood products prepared in homes, restaurants and sushi bars should be consumed in a shorter time than industrially prepared products (1). Several factors have been stated to be effective in a large number of food poisoning cases reported in relation to sushi consumption $(10,11)$. The fact that other foodstuffs used in making sushi are prepared in advance for quick service and possible contaminations of hands and other tools and equipment during the process may lead to an increase in the incidence of potential foodborne pathogens (2). Due to the reasons such as fish and other seafood products used in the preparation of the product, other mixtures such as vegetables and rice and also being consumed raw, hygiene of raw material and business, possible presence of pathogenic microorganisms (Salmonella spp., Vibrio parahaemolyticus, Staphylococcus aureus, Vibrio cholerae, Bacillus cereus, Listeria monocytogenes), parasites (Anisakiasis etc.) and viruses (Norovirus) can cause health problems $(1,6,12$, 13). Considering the growing popularity of sushi and other raw seafood dishes especially worldwide, it would be beneficial to raise awareness about the safety of raw seafood products consumption.

In the present study, it was aimed to determine the hygiene level of the products at the consumption points serving fresh sushi (sushi bar, sushi buffet, hotel, restaurant etc.) in Antalya, to evaluate the microbiological quality and preparation conditions and to determine preventive measures to increase food safety in order to provide information about the possible health risks associated with the increased consumption of ready-to-eat sushi.

For this purpose, the samples were examined for E. coli as hygiene indicator microorganism, specific food-borne pathogens by the numbers of coagulase-positive $S$. aureus and $V$. paraheamolyticus and presence of Salmonella spp.

\section{MATERIAL AND METHOD}

\section{Sampling and preparation for analysis}

Between June-July 2017, 60 samples of sushi $(\mathrm{N}=60)$ obtained from the consumption points serving fresh sushi (sushi bar, sushi buffet, hotel, restaurant etc.) in the province of Antalya on different days were used in this research study. Sushi samples taken into sterile containers under aseptic conditions were placed in polyethylene styrofoam boxes $\left(2-4{ }^{\circ} \mathrm{C}\right)$ containing ice and were delivered to the laboratory in a short time. Sample size and weight were determined as $5.00 \pm 0.88 \mathrm{~cm}$ and $21.00 \pm 1.74 \mathrm{~g}$, respectively. Microbiological analyses were carried out with two replications.

\section{Microbiological analyses}

Twenty-five g sample was homogenized in $225 \mathrm{ml}$ MRD (Maximum Recovery Diluent, MRD-Oxoid CM0733, UK) and aliquots of $0.5 \mathrm{ml}$ of prepared dilution were spread-plated onto Chromocult TBX Agar (Oxoid CM0945, UK). Plates were first incubated at $30 \pm 1{ }^{\circ} \mathrm{C}$ for $4 \pm 1 \mathrm{~h}$, then at $44 \pm 1{ }^{\circ} \mathrm{C}$ for $18 \pm 2 \mathrm{~h}$ and growing blue-green colonies were determined as Escherichia coli. No confirmation has been made since chromogenic medium was used. The strain E. coli ATCC 25922 (ATCC $^{\circledR} 25922^{\mathrm{TM}}$, USA) was used as a positive control (14).

Five $\mathrm{g}$ sample was homogenized with $45 \mathrm{ml} \mathrm{MRD} \mathrm{for}$ coagulase-positive Staphylococcus aureus (CFU/g) count, aliquots of 0.4-0.3-0.3 $\mathrm{ml}$ of this dilution (a total of $1 \mathrm{ml}$ ) by adding 5\% Egg Yolk Tellurite (Becton-Dickinson, BBL-212357, USA) were spread-plate onto previously prepared Baird Parker Medium Agar (Oxoid CM0275, UK). The plates were incubated at $35 \pm 1^{\circ} \mathrm{C}$ for $48 \mathrm{~h}$. At the end of the incubation, black-gray shiny colonies with a diameter of $2-3 \mathrm{~mm}$, surrounded by round, convex, smooth, narrow, bright zoned area in plates are considered as possible $S$. aureus colonies and all developing typical colonies were counted. Confirmation of typical colonies was performed by Staphylase (Staphylase Test Kit, Oxoid DR0595, UK) test. Colonies forming a visible agglutination were considered as coagulase-positive $S$. aureus. If the coagulase (staphylase) test result is positive, the number of $S$. aureus was determined as $\mathrm{CFU} / \mathrm{g}$ by multiplying the counted colonies by the dilution coefficient. The strain $S$. aureus ATCC 25923 (ATCC ${ }^{\circledR} 25923^{\text {TM }}$, USA) was used as a positive control (15).

Twenty-five g sample was homogenized with $225 \mathrm{ml}$ alkaline peptone water (APW, Merck 101800, Germany) (containing $3 \% \mathrm{NaCl}$ ), incubated at $35-37{ }^{\circ} \mathrm{C}$ for $18-24 \mathrm{~h}$ for Vibrio parahaemolitycus count. The content taken from the upper part of this enrichment medium using a loop without shaking was spread-plate onto Thiosulfate-Citrate-Bile Salts-Sucrose Agar (TCBS, Hardy Diagnostics, USA) (containing 3\% NaCl) and incubated at $35-37{ }^{\circ} \mathrm{C}$ for $18-24 \mathrm{~h}$. Round colonies with a diameter of $2-3 \mathrm{~mm}$ and green-blue in the middle were evaluated as $V$. parahaemolitycus and confirmation of typical colonies was performed by catalase, oxidase test and $\mathrm{API}{ }^{\circledR} 20 \mathrm{E}$ (BioMerieux, France) biochemical reagent kit (16).

Twenty-five g sample was taken into $225 \mathrm{ml}$ buffered peptone water for Salmonella spp. identification and was incubated at $37 \pm 1{ }^{\circ} \mathrm{C}$ for $16-20 \mathrm{~h}$. After incubation, $1 \mathrm{ml}$ of this suspension was transferred into $10 \mathrm{ml}$ of Muller-Kauffmann Tetrathionate-Novobiocin Broth (MKT'Tn-Oxoid CM1048, UK) for selective enrichment. Tubes were incubated at $37 \pm 1^{\circ} \mathrm{C}$ for 6-8h. Concordantly, $10 \mathrm{ml}$ of pre-enrichment suspension were transferred into Rappaport Vassiliadis Soy Broth (RVS Oxoid CM0886, UK) and incubated at $41.5 \pm 1{ }^{\circ} \mathrm{C}$ for $6-8 \mathrm{~h}$. Aliquots of these secondary enrichment broth were then spread-place onto Xylose Lysine Deoxycholate Agar (XLDOxoid CM0469, UK) and Brilliant Green Agar-Modified Agar (BGA-Oxoid CM0329, UK) using a loop and typical colonies were examined. Positive Salmonella spp. samples with typical colonies were confirmed using a Vidas device (mini VIDAS ${ }^{\circledR}$, BioMerieux, France) (17).

\section{RESULTS}

Numbers of E. coli, coagulase-positive S. aureus, $V$. parahaemolitycus of 60 analyzed sushi samples were calculated using base-10 logarithms and given as log CFU/g in Table 1. Salmonella spp. is presented as absent/present in Table 1.

\section{DISCUSSION}

RTE sushi is considered a kind of potentially hazardous food because it contains perishable ingredients. If it is not prepared in a hygienic procedure and stored at low temperature, it may cause food poisoning (2). It is recommended by ICMSF (International Commission on Microbiological Specifications for Foods) that food containing seafood products should be kept at temperatures below or close to $5^{\circ} \mathrm{C}(8)$. E. coli count in food products, which have been used to indicate direct or indirect fecal contamination, is a method used to indicate the cleanliness in food handling as well as the appropriateness of storage condition $(2,11)$. According to our study results, $E$. coli number was found to be ranging from ND (not detected the bacteria) and $3.96 \log \mathrm{CFU} / \mathrm{g}$ in $15 / 60$ samples $(25 \%)$ and $2.90 \log \mathrm{CFU} / \mathrm{g}$ on average, and $75 \%$ of the samples were 
Table 1 Microorganisms analyzed in sushi samples and their numbers $(\mathrm{N}=60)$

\begin{tabular}{|c|c|c|c|c|}
\hline \multirow{2}{*}{$\begin{array}{c}\text { Number of } \\
\text { microorganisms } \\
(\log \mathrm{CFU} / \mathrm{g})\end{array}$} & \multicolumn{4}{|c|}{ Indicator and Pathogen Microorganisms Levels (sample-\%) } \\
\hline & Escherichia coli & $\begin{array}{l}\text { Staphylococcus aureus } \\
\text { (coagulase positive) }\end{array}$ & $\begin{array}{c}\text { Vibrio } \\
\text { parabaemolitycus }\end{array}$ & $\begin{array}{l}\text { Salmonella spp. } \\
(+/-)\end{array}$ \\
\hline ND & $0.0(75.0 \%)$ & $0.0(83.3 \%)$ & $0.0(78.3 \%)$ & $58.0(96.7 \%)$ \\
\hline $1.00<2.00$ & ND & ND & ND & \\
\hline $2.00<3.00$ & $9.0(15.0 \%)$ & $4.0(6.7 \%)$ & $9.0(15.0 \%)$ & \\
\hline $3.00<4.00$ & $6.0(10.0 \%)$ & $5.0(8.3 \%)$ & $4.0(6.7 \%)$ & $2.0(3.3 \%)$ \\
\hline $4.00<5.00$ & ND & $1.0(1.7 \%)$ & ND & \\
\hline $5.00 \geq$ & ND & ND & ND & \\
\hline Min. & ND & ND & ND & - \\
\hline Max. & 3.96 & 4.84 & 3.86 & - \\
\hline Means & 2.90 & 3.24 & 2.82 & - \\
\hline TOTAL & $15.0(25.0 \%)$ & $10.0(16.7 \%)$ & $13.0(21.7 \%)$ & $2.0(3.3 \%)$ \\
\hline
\end{tabular}

CFU: Colony Forming Unit, N: Number of samples, ND: Not Detected

found to be negative for this microorganism (Table 1). The recommended limit for good quality foods $(2.7 \mathrm{log} \mathrm{CFU} / \mathrm{g})$ was exceeded in 9 samples for E. coli (18). It is considered that this situation results from possible contamination due to poor hygiene and sanitation in operation, personnel or equipment during production and preservation in businesses, raw material and other reasons (production line design, water, etc.).

Staphylococcus aureus is a microorganism with variable virulence and produces toxin when it is exceeded the level of $5 \mathrm{log}$ CFU/g. Toxin dose of less than $1.0 \mu \mathrm{g}$ may produce symptoms of intoxication (19). Although S. aureus is not part of the normal fish microflora, it is reported that it is possible to have contamination arising from nutrients involved in fish products prepared with personnel and/or other foods during the process $(2,11)$. In this study, coagulase-positive $S$. aureus was detected ranging from ND and $4.84 \mathrm{log} \mathrm{CFU} / \mathrm{g}$ in 10/60 samples $(16.7 \%)$ (Table 1$)$.

According to the results, the presence of a sample with a potential to produce toxin indicates that proper personnel hygiene and other cleaning procedures are disrupted where the relevant sample is provided. $S$. aureus contamination denotes a lack of good hygienic practices by businesses, spoilage after harvest due to diseases in fish used in the preparation of raw materials or sushi or the possibility of cross contamination during raw material and/or process stages $(11,20)$.

Vibrio parabaemolyticus is a microorganism that is more common in the hot summer months and naturally found in marine environments and constitutes an average of $30 \%$ of the total microbial load in seawater. The primary control measure is mostly intended to prevent the proliferation of this organism $(8,21)$. In our country, there is a legal regulation for the absence of this microorganism in frozen and processed fish products (22). According to our study results, $V$. parahaemolyticus presence was detected in the level of $2.82 \mathrm{log}$ $\mathrm{CFU} / \mathrm{g}$ on average in $13 / 60$ samples $(21.7 \%)$, and it was found to be noncompliance with the relevant regulation (Table 1).

Salmonella spp. is a pathogen bacterium causes food poisoning and infection, and it is reported that even $<10 \mathrm{CFU}$ Salmonella spp. organisms may lead to infection (2). Possible contamination of Salmonella spp. in raw materials, food manufacturing, tools and equipment used in the food chain, processing and retailing stages can cause very important health problems for public health. In general, all raw foods including fish, shellfish, fruits, vegetables, poultry, eggs, other foods of animal origin, dairy products and crops are always at risk for non-typhoid Salmonella spp. (23). Although there is a close relationship between RTE food consumption and Salmonellosis, previous studies have reported that the presence of Salmonella spp. in sushi is not very common in general (9). Although outbreaks related to Salmonella spp. infected fishery products (fish borne) is not very common, it has been reported that after sushi consumption, 62 people in 11 different locations in The United States of America experienced food poisoning and diagnosed with Salmonellosis. In our country, there is no RTE food definition and no legal regulation has been published specifically for these foods. Turkish Food Codex (TFC) (24) and Regulation on Seafood (22) report that Salmonella spp. should not be present $(0 / 25 \mathrm{~g}-\mathrm{ml})$ in fishery products and processed or frozen fish products. The amount of Salmonella spp. in RTE foods has been determined as $0 / 25 \mathrm{~g}$ by the European Commission (25). According to our study results, $2 / 60$ samples $(3.3 \%)$ were found to be noncompliance with the relevant regulations (Table 1$)$.

A study examining sushi samples taken in winter (DecemberFebruary) demonstrated that positive sample counts were determined as $11 / 447(2.5 \%)$ for E. coli and $7 / 447(16 \%)$ for coagulase-positive staphylococci while Salmonella spp. (0/447) and $V$. parahaemolyticus $(0 / 155)$ were not detected. In samples taken in summer (June-August), $V$. parahaemolyticus was detected in 1/158 sample, examined samples were negative for Salmonella, determined limit was exceeded in 6/404 samples for E. coli and 2/404 samples for coagulase-positive staphylococci (8). Atanasovva et al. (11) revealed that E. coli was detected ranging from 2.0 and $3.3 \mathrm{log}$ CFU/g in 24/125 fresh sushi samples, Staphylococcus spp. with high prevalence was detected ranging from 3.8 and $4.7 \mathrm{log} \mathrm{CFU} / \mathrm{g}$ in all samples and the prevalence was high $(125 / 125)$, Salmonella spp. was found in $1 / 125(0.8 \%)$ sample and Vibrio spp. were not detected in any sample. In several studies, it is shown that $V$. parabaemolyticus contamination in samples may originate from fishery and shellfish products used in the preparation of sushi, Salmonella spp. and $S$. aureus contamination may be caused by vegetables, mayonnaise containing raw egg and personnel-related $(3,8)$. 
In 38 samples obtained from consumption points such as restaurant, sushi bar, Salmonella spp. and V. parahaemolyticus were not found, coagulase-positive staphylococci was detected ranging from 2.00 and $3.60 \mathrm{log} \mathrm{CFU} / \mathrm{g}$ in 16/38 samples $(42.11 \%)$ and found at an unacceptable level in 6 samples (3). Liang et al. (2) reported in packaged sushi samples taken from 120 different consumption points that $E$. coli and $S$. aureus counts were 1.0 and $2.3 \mathrm{log} \mathrm{CFU} / \mathrm{g}$ on average, respectively and Salmonella spp. was not detected in any samples. Wong and Cheung (21) indicated that the number of E. coli was found as $20 / 102(19.6 \%)$ in 102 fresh sushi samples, V. parahaemolyticus was detected in only $3 / 102$ samples $(2.9 \%)$, the presence of $E$. coli and $V$. parahaemolyticus results from inadequate hygiene practices in pre-harvest, harvest and sushi processing stages and possible bacterial contamination in fishery and other aquaculture products. Coagulase-positive staphylococci, $V$. parahaemolyticus and Salmonella spp. could not be detected in 36 samples taken from several restaurants, whereas positive E. coli count was found as 2/36 (5.6\%) (7). Salmonella spp. was not detected in 28 sushi samples obtained from 7 different businesses whereas E. coli was found in 3.6\% of samples (9). E. coli was detected in 38/50 fresh sushi samples taken from sushi bars and $S$. aureus were found in 11/50 samples (26). Staphylococcus spp. was determined ranging from 3.3 and 3.8 $\log \mathrm{CFU} / \mathrm{g}$ in samples obtained from 20 different retail points serving sushi, $S$. aureus count was found less than $2 \log \mathrm{CFU} / \mathrm{g}$ on average (27).

According to the study results, it is considered that different findings may proceed from microbial contaminations to be occurred pre-harvest during and post-harvest in fishery and other seafood products used in making sushi (21), operational and personnel hygiene during the entire process, possible contaminations during preservation of final product sushi and other raw materials and deficiencies in cold storage applications.

\section{CONCLUSION}

In order to maintain the quality of food products, they must be kept at low temperatures. United States Food and Drug Administration (FDA) that in order to eliminate the possible parasite presence in raw seafood used in sushi, it is necessary to wait for 7 days below $-20{ }^{\circ} \mathrm{C}$ or for $15 \mathrm{~h}$ below $-35^{\circ} \mathrm{C}$. According to EC (28) and TFC (24), in order to kill other parasites other than Trematodes in fishery products to be consumed raw, freezing process should be applied not less than $24 \mathrm{~h}$ at $-20{ }^{\circ} \mathrm{C}$ or less than $15 \mathrm{~h}$ at $-35^{\circ} \mathrm{C}$, and there is a regulation to preserve fresh fishery products at a temperature close to melting point. Due to the high potential of food poisoning of raw seafood products, they should be transported under temperature control in order to reduce microbial development and should be kept at $\leq 5{ }^{\circ} \mathrm{C}$ until the process in the businesses (21). It is initially necessary to choose suitable raw materials for microbial quality to make a healthy sushi. It should be taken into consideration that sushi rice is not a good substrate for microbiological development because of its low $\mathrm{pH}(<4.6)$, however; it might contribute to inhibiting the development of lactic acid bacteria since it contains fermented carbohydrates $(1,4,6)$. As sushi is highly sensitive to deviations from optimal storage temperature, positive correlations between microorganism counts and storage temperatures may lead to loss of quality during sell-by date (29). Careful selection of other nutrients used in making sushi, maintenance of cold chain during preparation processes and storage, compliance with hygiene and sanitation rules in personnel, equipment and service $(3,11)$ should be adopted as the basic principles in order to maintain the microbiological quality in the final product. In addition, businesses ensuring their personnel to receive hygiene training on a regular basis and increased frequency of inspections by authorities will provide a significant contribution to minimize sushi-related food poisoning. GMP (Good Manufacturing Practice) or HACCP (Hazard Analysis and Critical Control Point) food safety control systems incorporating into the manufacturing process by businesses will help strengthen the food safety control. The fact that consumers behave sensitively during transportation and storage of ready-prepared sushi, prefer places making good quality sushi and care about shelf life, people with chronic conditions such as immune system insufficiency, pregnancy and cancer should be more careful about sushi consumption due to their risks will contribute to healthy sushi consumption.

\section{CONFLICTS OF INTEREST}

We declare that there are no conflicts of interest among the authors of the article.

\section{REFERENCES}

1. Lorentzen G, Breiland MSW, Cooper M, Herland H. Viability of Listeria monocytogenes in an experimental model of nigiri sushi of halibut (Hippoglossus hippoglossus) and salmon (Salmo salar). Food Control. 2012;25(1):245-48.

2. Liang WL, Pan YL, Cheng HL, Li TC, Yu PHF, Chan SW. The microbiological quality of take-away raw salmon finger sushi sold in Hong Kong. Food Control. 2016;69:45-50.

3. Muscolino D, Giarratana F, Beninati C, Tornambene A, Panebianco A, Ziino G. Hygienic-sanitary evaluation of sushi and sashimi sold in Messina and Catania, Italy. Ital J Food Saf. 2014;3(2):134-36.

4. Corapci B, Guneri N. Yengeç, istakoz surimi ve füme somon ile hazırlanmıs makizușinin $4 \pm 1{ }^{\circ} \mathrm{C}$ 'de duyusal, kimyasal ve mikrobiyolojik kalitesi. J Food Health Sci. 2016;2(4):159-70.

5. Mol S, Ucok Alakavuk D, Ulusoy S. Effects of modified atmosphere packaging on some quality attributes of a readyto-eat salmon sushi. Iran J Fish Sci. 2014;13(2):394-406.

6. Hoel S, Mehli L, Bruheim T, Vadstein O, Jakobsen AN. Assessment of microbiological quality of retail fresh sushi from selected sources in Norway. J Food Prot. 2015;78(5):97782.

7. Batista CM, Ribeiro MLR, de Souza MJF, Borges LJ de Castro Ferreira TAP, Andre MCP. Microbiological and physicochemical qualities of sushi and sashimi from Japanese Restaurants in Brazil. J Food Nutr Res. 2017;5(10):729-35.

8. Authority NSWF. Report on food handling practices and microbiological quality of sushi in Australia. Sydney, Australia: Author; 2008. p. 1-26.

9. Ramires T, Iglesias MA, Vitola HS, Nuncio ASP, Kroning IS, Kleinubing NR, et al. First report of Escherichia coli O157:H7 in ready-to-eat sushi. J Appl Microbiol. 2020;128(1):30109. https://doi.org/10.1111/jam.14456.http://www.fda. gov/downloads / Food/FoodborneIllnessContaminants / UCM297627.pdf.

10. Barralet J, Stafford R, Towner C, Smith P. Outbreak of Salmonella Singapore associated with eating sushi. Communicable Diseases Intelligence Quarterly Report. 2004;28(4):527-28.

11. Atanassova V, Reich F, Klein G. Microbiological quality of sushi from sushi bars and retailers. Journal of Food Protection. 2008;71(4): 860-64. 
12. Altekruse SF, Cohen ML, Swerdlow DL. Emerging foodborne diseases. Emerg Infect Dis. 1997;3(3):285-93.

13. Nawa Y, Hatz C, Blum I. Sushi delights and parasites: the risk of fishborne and foodborne parasitic zoonoses in Asia. Clinical Infectious Diseases. 2005;41(9):1297-303.

14. Healt Protection Agency. Direct enumeration of Escherichia coli, National Standard Method F 20, Issue 1. 2004.

15. Benntt W, Lancette GA. Bacteriological Analytical Manual (Chapter 12): Staphylococcus aureus. Department of Health and Human Services, 8th ed. US Food and Drug Administration; 2001.

16. Kaysner CA, DePaola AJ. Bacteriological Analytical Manual, Chapter 9, Vibrio. http://www. fda. gov/ Food/ScienceResearch / Laboratory Methods / BacteriologicalAnalytical Manual BA M/ucm070830. 2004. Access date: 15/01/2020.

17. ISO P. Microbiology of food and animal feeding stuffs. Horizontal method for the detection of Salmonella spp. Geneva, Switzerland: ISO Norm 6579: 2002.

18. ICMSF 1986. Microorganisms in foods 2. Sampling for microbiological analysis: principles and specific applications, 2nd ed. International Commission on Microbiological Specifications for Foods.

19. Food and Drug Administration. Bad bug book: handbook of foodborne pathogenic microorganisms and natural toxins. Center for Food Safety and Applied Nutrition; 2012.

20. Austin B, Austin DA. Bacterial Fish Pathogens. Heidelberg: Springer; 2012. p. 652.

21. Wong P, Cheung KT. Prevalence of foodborne pathogen in fresh sushi at sushi take-out stores in Hong Kong. EC Microbiol. 2019;15(10):1060-68.

22. Regulation on Seafood. 10.03.1995 Official Journal Number: 22223, Different Official Journal Number: 21.09.2008-27004. 2008 .

23. Gomez-Aldapa CA, del Refugio Torres-Vitela M, VillarruelLopez A, Castro-Rosas J. The role of foods in Salmonella infections. Salmonella-a dangerous foodborne pathogen. Mahmoud, BSM. Croatia: Intech Publisher ed. 2012; 21-46.

24. Turkish Food Codex. Regulation of Microbiological Criteria. 29.12.2011/Official Journal Number: 28157. 2011.

25. EC. Commission Regulation (EC) No 2073/2005 of 15 November 2005 on microbiological criteria for foodstuffs. Official Journal of the European Union. 2004;L 50:1-26.

26. Abdel-Hakeem SS, Mahmoud GAE, Abdel-Hafeez $\mathrm{HH}$. Evaluation and microanalysis of parasitic and bacterial agents of Egyptian fresh sushi, salmo salar. Microscopy and Microanalysis. 2019;25(6):1498-508.

27. Li H, Stegger M, Dalsgaard A, Leisner JJ. Bacterial content and characterization of antibiotic resistant Staphylococcus aureus in Danish sushi products and association with food inspector rankings. Int J Food Microbiol. 2019;305:108244. https:/ / doi. org/10.1016/j.ijfoodmicro.2019.108244.

28. EC. Commission Regulation (EC) No 853/2004 of the
European Parliament and of the Council of 29 April 2004 laying down specific hygiene rules for food of animal origin. Official Journal of the European Union. 2004;L 139:30-205.

29. Hoel S, Jakobsen AN, Vadstein O. Effects of storage temperature on bacterial growth rates and community structure in fresh retail sushi. J Appl Microbiol. 2017;123(3):698-709. 